\title{
Effect of outlet drying temperature and milk fat content on the physicochemical characteristics of spray-dried camel milk powder
}

\author{
Ahmed Zouari, Ítalo Tuler Perrone, Pierre Schuck, Frédéric Gaucheron, Anne \\ Dolivet, Hamadi Attia \& Mohamed Ali Ayadi
}

To cite this article: Ahmed Zouari, Ítalo Tuler Perrone, Pierre Schuck, Frédéric Gaucheron, Anne Dolivet, Hamadi Attia \& Mohamed Ali Ayadi (2018): Effect of outlet drying temperature and milk fat content on the physicochemical characteristics of spray-dried camel milk powder, Drying Technology, DOI: 10.1080/07373937.2018.1526189

To link to this article: https://doi.org/10.1080/07373937.2018.1526189

曲 Published online: 20 Nov 2018.

Submit your article to this journal $₫$

View Crossmark data ð 


\title{
Effect of outlet drying temperature and milk fat content on the physicochemical characteristics of spray-dried camel milk powder
}

\author{
Ahmed Zouari $^{\mathrm{a}, \mathrm{b}}$, Ítalo Tuler Perrone ${ }^{\mathrm{b}, \mathrm{c}}$, Pierre Schuck ${ }^{\mathrm{b}}$, Frédéric Gaucheron ${ }^{\mathrm{b}}$, Anne Dolivet ${ }^{\mathrm{b}}$, Hamadi Attia ${ }^{\mathrm{a}}$, \\ and Mohamed Ali Ayadi ${ }^{\mathrm{a}}$ \\ ${ }^{a}$ Valuation, Security and Food Analysis Laboratory, National Engineering School of Sfax, Sfax University, Sfax, Tunisia; bscience and \\ Technology of Milk and Egg, INRA-Agrocampus, Rennes, France; 'Department of Food Technology, Federal University of Viçosa, Minas \\ Gerais, Brazil
}

\begin{abstract}
A composite face-centered experimental design was used to investigate the influence of spray drying conditions on the physicochemical characteristics of camel and cow milk powders. Response surface methodology (RSM) was deployed to appraise the effects of these processing parameters (the outlet drying temperature and the milk fat content) on water activity $\left(a_{w}\right)$, glass transition temperature $\left(T_{g}\right)$, bulk density, and free fat quantity. According to RSM analysis, it was noticed that the $a_{w}$ and the $T_{g}$ were primarily influenced by the outlet drying temperature instead of by milk fat content. Our results highlighted the negative effects of milk fat content and of the outlet drying temperature on the bulk density as well as on the free fat quantity of camel milk powder. Likewise, our findings underlined the negative effect of the outlet drying temperature on the bulk density of cow milk powder. However, the increase of fat content has led to the overexposure of fat at the free surface of the cow milk powder. Our results suggested a marked similarity of the overall thermodynamic behavior of both milks, during drying. Nevertheless, some differences were highlighted regarding the structuring of the particles of camel milk powder.
\end{abstract}

\section{ARTICLE HISTORY}

Received 20 August 2017

Revised 16 May 2018

Accepted 10 September 2018

\section{KEYWORDS}

Camel milk; spray drying; milk powder; response

surface methodology

\section{Introduction}

Cow milk represents a relevant source of raw material for many dairy powder manufacturers. Most researchers have focused their studies on the production, storage stability, and functionalities of cow milk powder. However, there is a huge lack of information about other milk powders such as camel milk powder. In fact, in arid and semi-arid regions, camel milk is the most consumed milk for its therapeutic and nutritional properties. ${ }^{[1]}$ Its overall composition is similar to that of cow milk. ${ }^{[2]}$ However, some profound and specific differences were found concerning the composition and the hydrophobicity of the caseins and whey proteins. ${ }^{[3]}$ In addition, some researchers have reported that the size distribution of both fat globules and casein micelles was relatively different from that observed for cow milk. ${ }^{[4,5]}$

Actually, milk proteins are surface-active compounds. Their compositions seem to control the transport of milk colloids (e.g. fat globules) to the surface of powder particles. ${ }^{[6]}$ Several studies have reported that the morphology of dried particles was related to the behavior of milk fat globules, during drying. ${ }^{[7,8]}$ In fact, it was found that, the size distribution of milk fat globules was involved in the internal development of dried particles; while, the final shape of these particles depended particularly on the drying temperature intensity. ${ }^{[7,9]}$ Indeed, it was noticed that, the outlet drying temperature has influenced the particle volume; and has induced the appearance of cracks and pores on its surface. ${ }^{[6,8]}$ These findings could strongly be correlated to the bulk density and free fat evolution of milk powder, during drying and storage. ${ }^{[8,10,11]}$

As soon as the drying was progressing, fats and proteins started to accumulate on the surface of milk powder particles, at the expense of lactose. ${ }^{[11,12]}$ Several studies highlighted the importance of the surface composition of dairy powder particles. ${ }^{[11,13,14]}$ Conventionally, the surface composition was expected to control the functionalities (e.g. rehydration properties $^{[15]}$ ) and the storage ability (e.g. amorphous lactose stability ${ }^{[16]}$ ) of dairy powders. In fact, at a low relative 
Table 1. Physicochemical characteristics of whole cow and camel milks.

\begin{tabular}{lccccccc}
\hline & $\mathrm{pH}^{*}$ & $a_{w}{ }^{*}$ & Solid matter (\%) & Fats (\%) & Proteins (\%) & Lactose (\%) & Ash (\%) \\
\hline Cow milk & 6.7 & 0.96 & $12.2 \pm 0.1^{\mathrm{a}}$ & $3.9 \pm 0.1^{\mathrm{a}}$ & $3.1 \pm 0.2^{\mathrm{a}}$ & $4.5 \pm 0.3^{\mathrm{a}}$ & $0.9 \pm 0.1^{\mathrm{a}}$ \\
Camel milk & 6.5 & 0.96 & $11.8 \pm 0.2^{\mathrm{b}}$ & $2.7 \pm 0.1^{\mathrm{b}}$ & $3.2 \pm 0.2^{\mathrm{a}}$ & $4.9 \pm 0.1^{\mathrm{a}}$ & $0.9 \pm 0.2^{\mathrm{a}}$ \\
\hline
\end{tabular}

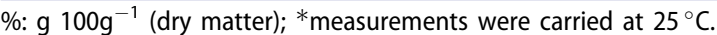

Same letter in the same column represent the statistical data significance $(p>0.05)$

Table 2. The experimental domain of the central composite face-centered design applied to study the physicochemical properties of camel and cow milk powders.

\begin{tabular}{lccc}
\hline Coded level & -1 & 0 & 1 \\
\hline $\begin{array}{l}\text { Experimental level } \\
\mathrm{X}_{1} \quad \text { Milk fat content }\left(\mathrm{g} \mathrm{mL}^{-1}\right)\end{array}$ & 1 & 14 & 27 \\
$\mathrm{X}_{2} \quad \begin{array}{c}\text { Outlet drying } \\
\text { temperature }\left({ }^{\circ} \mathrm{C}\right)\end{array}$ & $76.5 \pm 3.8$ & $86.8 \pm 3.8$ & $100.3 \pm 3.8$ \\
$\quad \begin{array}{l}\text { Normalized outlet } \\
\text { drying temperature }\left({ }^{\circ} \mathrm{C}\right)\end{array}$ & 0 & 12 & 24 \\
& & & \\
\hline
\end{tabular}

*Mean of six experiments.

humidity ( $\mathrm{RH}<20 \%$ ), proteins were, in most of the cases, responsible of water uptake during milk powder storage. This phenomenon was acknowledged to delay or to shorten the lactose crystallization rate. ${ }^{[1]}$ Indeed, dairy powders were assimilated to a glassy amorphous material, in which the mobility of solid compounds was extremely limited. ${ }^{[18]}$ Even if they appeared stable, these amorphous compounds would be in an instable energetic state. Their stability was directly linked to the glass transition temperature $\left(T_{g}\right)$. Since water was stated to be the main plasticizer in dried food products, a drastic decrease of glass transition temperature, could be observed as the water content increased. ${ }^{[19]}$ Exceeding the $T_{g}$, the mobility of the amorphous compounds was enhanced, resulting in an acceleration of the rate of the deteriorative reactions. ${ }^{[20]}$

In dairy powders, the evolution of lactose (i.e. the main amorphous compound) depended on the moisture content and on the hygroscopicity of the milk powder. ${ }^{[21]}$ Some researchers highlighted that, at constant relative humidity, the outlet drying temperature seemed to control the final moisture content of milk powder. ${ }^{[22,23]}$ Recently, it has been reported that, the knowledge of water activity was more relevant than that of moisture content. ${ }^{[2,25]}$ In fact, water activity was defined as the available water to allow bacterial growth or initiating chemical reactions. In case of dried food, higher water activity participated in deteriorating the physical stability of milk powder (e.g. lactose crystallization, powder stickiness, and caking). ${ }^{[26]}$ Since fats are non-water absorbent compounds, the water activity could be related to the outlet drying temperature and to the powder moisture content. ${ }^{[24,27]}$

In order to enlarge the consumption spectra of camel milk, it was highly important to apply some stabilization treatments, such as spray drying. Actually, few researchers have reported some information about the physicochemical and the sensory properties of spraydried camel milk powder. ${ }^{[28,29]}$ However, none of these studies have investigated the effect of drying parameters on the production of camel milk powder. For this reason, this work aimed at understanding the influence of the air outlet drying temperature and of the milk fat content, on water activity $\left(a_{w}\right)$, glass transition temperature $\left(T_{g}\right)$, bulk density, and the free fat of camel milk powder. To develop a valuable study, we have conducted a comparison with cow milk powder, produced under the same drying conditions. In this case, it was fundamental to consider the physicochemical differences between camel and cow milks, before drying.

\section{Material and methods}

\section{Milk samples}

Fresh Tunisian cow and camel milks were collected from separated Tunisian farms (Sfax and Gabes governorates, respectively). Then, milk samples were transported to the laboratory at $4{ }^{\circ} \mathrm{C}$ within $2 \mathrm{~h}$; and were microbiologically stabilized by the addition of sodium azide $(0.02 \%, \mathrm{w} / \mathrm{w})$. Milk freezing (at $\left.-20^{\circ} \mathrm{C}\right)$ was mandatory to ensure its preservation for several months. Before any experiment, milk samples were thawed at $4{ }^{\circ} \mathrm{C}$ during $48 \mathrm{~h}$. After thawing, there was no observed aggregates in milk samples.

\section{Physicochemical composition of milks}

The ash, proteins, fat, and lactose contents of camel and cow milks (Table 1) were determined according to the Official Methods of Analysis (AOAC International, 2000). ${ }^{[30]}$ The statistical differences $(p<.05)$ between both milk compositions were performed SPSS 19 software (IBM SPSS statistics, Version 19, USA) following the Student's $t$-test.

\section{Spray drying conditions}

Before drying, the fat content of camel and cow milks was adjusted to 1,14 , and $27 \mathrm{~g} \mathrm{~L}^{-1}$, following optimized skimming conditions (Table 2). The different milk samples were equilibrated in a water-bath to reach a temperature of $15^{\circ} \mathrm{C}$. Then, the samples were 
Table 3. The central composite face-centered experimental design used to study the physicochemical characteristics of camel and cow milk powders.

\begin{tabular}{|c|c|c|c|c|c|c|c|c|c|c|}
\hline \multirow[b]{3}{*}{ Run } & \multicolumn{2}{|c|}{ Factors } & \multicolumn{8}{|c|}{ Powder characteristics } \\
\hline & \multirow{2}{*}{$\begin{array}{l}\text { Outlet drying } \\
\text { temperature }\left({ }^{\circ} \mathrm{C}\right)\end{array}$} & \multirow{2}{*}{$\begin{array}{c}\text { Milk fat } \\
\text { content }\left(\mathrm{g} \mathrm{L}^{-1}\right)\end{array}$} & \multicolumn{2}{|c|}{ Water activity } & \multicolumn{2}{|c|}{$\begin{array}{l}\text { Glass transition } \\
\text { temperature }\left({ }^{\circ} \mathrm{C}\right)\end{array}$} & \multicolumn{2}{|c|}{$\begin{array}{c}\text { Bulk } \\
\text { density }\left(\mathrm{kg} \mathrm{m}^{-3}\right)\end{array}$} & \multicolumn{2}{|c|}{ Free fat (\%)\# } \\
\hline & & & Cow & Camel & Cow & Camel & Cow & Camel & Cow & Camel \\
\hline 1 & 0 & 27 & 0.262 & 0.276 & 39.1 & 37.1 & 270 & 274 & 33.5 & 35.3 \\
\hline 2 & 12 & 14 & 0.222 & 0.213 & 39.5 & 40.2 & 359 & 192 & 39.2 & 20.6 \\
\hline 3 & 24 & 1 & 0.103 & 0.108 & 52.6 & 59.4 & 259 & 187 & 30 & 21.1 \\
\hline 4 & 12 & 14 & 0.232 & 0.203 & 41.6 & 42.2 & 359 & 187 & 39.2 & 23.6 \\
\hline 5 & 0 & 1 & 0.245 & 0.244 & 37.8 & 40 & 301 & 245 & 42.1 & 20 \\
\hline 6 & 12 & 14 & 0.242 & 0.223 & 41.5 & 40.5 & 359 & 192 & 39.2 & 23.6 \\
\hline 7 & 12 & 1 & 0.206 & 0.195 & 41.5 & 44.0 & 299 & 201 & 40 & 20 \\
\hline 8 & 0 & 14 & 0.286 & 0.276 & 33.9 & 35.3 & 327 & 220 & 36.3 & 24.7 \\
\hline 9 & 24 & 27 & 0.170 & 0.151 & 55.6 & 53.0 & 231 & 202 & 35 & 32.9 \\
\hline 10 & 12 & 27 & 0.215 & 0.217 & 51.5 & 47.0 & 245 & 208 & 34.9 & 37.3 \\
\hline 11 & 12 & 14 & 0.250 & 0.217 & 44.1 & 42.5 & 320 & 201 & 40.9 & 25.6 \\
\hline 12 & 12 & 14 & 0.240 & 0.247 & 42.1 & 37.4 & 320 & 211 & 40.9 & 28.6 \\
\hline 13 & 24 & 14 & 0.210 & 0.212 & 50.5 & 51.3 & 282 & 168 & 34.4 & 22.3 \\
\hline 14 & 12 & 14 & 0.260 & 0.207 & 40.1 & 40.5 & 320 & 201 & 40.9 & 25.6 \\
\hline
\end{tabular}

$\# \mathrm{~g} 100 \mathrm{~g}^{-1}$ of total powder fat.

spray-dried using a Bucchi mini Spray Dryer B-290 (Büchi Labortechnik AG, Flawil, Switzerland). For each run, the pre-heated air aspiration rate $\left(35 \mathrm{~m}^{3} \mathrm{~h}^{-1}\right)$, the feed flow rate $\left(0.6 \mathrm{~L} \mathrm{~h}^{-1}\right)$, and the air flow at the sprayer nozzle $\left(47.3 \mathrm{~m}^{3} \mathrm{~h}^{-1}\right)$ were held constant. Three inlet air drying temperatures (160, 180 , and $200^{\circ} \mathrm{C}$ ) were applied. The resulting outlet drying temperatures were averaged and normalized (Table 2). Camel and cow milk powders were then collected and conserved in plastic sterilized bags.

\section{Experimental design}

To carry out the influence of the milk fat content and the air outlet drying temperature (Table 2), a central composite face-centered experimental design (CCFD) was adopted. This design allows the quantification of the effect of each studied factor (three levels per factor) and the identification of its resulting interactions. In general, the CCFD is divided into four factorial points and four star points $(\alpha=1)$. The Design-Expert software (version 7.0.0, Stat Ease, USA, Stat-Ease Inc., MI, USA) was used to generate 14 experiments, including six center points (Table 3). The replication of the center points was mandatory and was involved in the estimation of the pure experimental error. Then, the characteristics of camel and cow milk powders were evaluated through the response surface methodology. The generalized response surface model follows a second-order polynomial equation as presented below:

$$
\begin{aligned}
y= & B_{0}+B_{1} X_{1}+B_{2} X_{2}+B_{11} X_{12}+B_{22} X_{22} \\
& +B_{12} X_{1} X_{2}
\end{aligned}
$$

where $y$ is the analyzed milk powder characteristic; $X_{1}$ and $X_{2}$ represent the studied variables; $B_{0}, B_{1}, B_{2}$,
$B_{12}$ are the model regression coefficients. The polynomial equations were presented using only the significant experimental model coefficients (Table 4). However, the coded model coefficients were used to describe the extent of the factor effect on the response (Table 5). In addition, only the significant models with a regression coefficient $R^{2}$ higher than $85 \%$ were accepted.

\section{Water activity}

The camel and cow milk powders $(\sim 2 \mathrm{~g})$ were poured into a specific capsule; and were placed in a hermetic chamber at $25^{\circ} \mathrm{C}$. The analysis of water activity was performed using an $a_{w}$-meter (Novasina RTD 200/0 and RTD 33, Pfäffikon, Switzerland).

\section{Glass transition temperature}

The glass transition temperatures $\left(T_{\mathrm{g}}\right)$ were primarily determined according to a mechanical test developed by Hogan et al., 2010. ${ }^{[31]}$ This technique allows the measurement of the normal force depression (initially fixed at $30 \mathrm{~N}$ ) following an axial compression test. In this test, we have used a laboratory rheometer (AR2000, TA Instruments UK, Ltd., Crawley, England), operating in a small amplitude shear-oscillation configuration $(0.1 \mu \mathrm{Nm}$ at $25 \mathrm{~Hz})$. Approximately $2 \mathrm{~g}$ of camel or cow milk powders were placed between a $40 \mathrm{~mm}$ steel plate and a Peltier plate system. This system enables the control of temperature from zero to $140^{\circ} \mathrm{C}$ at a rate of $2^{\circ} \mathrm{C} \mathrm{min}{ }^{-1}$. The evolution of the normal force was plotted against the used range of temperatures. The glass transition 
Table 4. Characteristics of the obtained models for the studied physicochemical properties of camel and cow milk powders.

\begin{tabular}{|c|c|c|c|c|}
\hline Powder characteristic & Models equations* & $R^{2}$ & Adjusted $R^{2}$ & CV (\%) \\
\hline \multicolumn{5}{|l|}{ Water activity } \\
\hline Cow milk & $=0.24-0.006 X_{1}-0.0002 X_{2}^{2}$ & 0.85 & 0.76 & 9.9 \\
\hline Camel milk & $=0.24-0.005 X_{1}-0.0003 X_{2}^{2}$ & 0.92 & 0.86 & 7.4 \\
\hline \multicolumn{5}{|c|}{ Glass transition temperature $\left({ }^{\circ} \mathrm{C}\right)$} \\
\hline Cow milk & $=39.8+0.4 X_{1}+0.03 X_{2}^{2}$ & 0.94 & 0.89 & 4.9 \\
\hline Camel milk & $=37.1+0.6 X_{1}-0.6 X_{2}+0.03 X_{2}^{2}$ & 0.94 & 0.89 & 4.7 \\
\hline \multicolumn{5}{|l|}{ Bulk density $\left(\mathrm{kg} \mathrm{m}^{-3}\right)$} \\
\hline Cow milk & $=243.2-3.7 X_{1}+0.1 X_{2}^{2}$ & 0.89 & 0.82 & 5.4 \\
\hline \multirow{2}{*}{\multicolumn{5}{|c|}{ 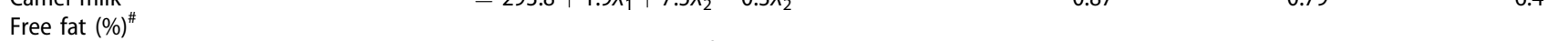 }} \\
\hline & & & & \\
\hline Cow milk & $=30-0.07 X_{2}+0.02 X_{2}^{2}$ & 0.89 & 0.84 & 6.47 \\
\hline Camel milk & $=21.9+0.08 X_{1}-0.17 X_{2}+0.02 X_{1} X_{2}-0.02 X_{1}^{2}$ & 0.91 & 0.85 & 7.75 \\
\hline
\end{tabular}

*Models were presented in term of the significant experimental coefficients $(p<.05) ;{ }^{\#} \mathrm{~g} 100 \mathrm{~g}^{-1}$ of total powder fat; $X_{1}$ : air outlet drying temperature; $X_{2}$ : milk fat content; CV: coefficient of variation.

Table 5. Effect of studied factors on physicochemical properties of camel and cow milk powders deduced from the coded models coefficients.

\begin{tabular}{|c|c|c|c|c|c|c|c|c|}
\hline \multirow[b]{2}{*}{ Factors } & \multicolumn{2}{|c|}{ Water activity } & \multicolumn{2}{|c|}{$\begin{array}{c}\text { Glass transition } \\
\text { temperature } \\
\left({ }^{\circ} \mathrm{C}\right)\end{array}$} & \multicolumn{2}{|c|}{$\begin{array}{c}\text { Bulk } \\
\text { density } \\
\left(\mathrm{kg} \mathrm{m}^{-3}\right)\end{array}$} & \multicolumn{2}{|c|}{ Free fat $(\%)^{\#}$} \\
\hline & Cow & Camel & Cow & Camel & Cow & Camel & Cow & Camel \\
\hline$x_{1}$ & - & - & + & + & - & - & NS & - \\
\hline$x_{2}$ & NS & NS & NS & + & NS & - & + & - \\
\hline$X_{1} X_{2}$ & NS & NS & NS & NS & NS & NS & NS & + \\
\hline$x_{1}^{2}$ & NS & NS & NS & NS & NS & NS & NS & - \\
\hline$x_{2}^{2}$ & - & - & + & + & + & - & + & NS \\
\hline
\end{tabular}

temperature was then determined, when a sharp decline of normal force was observed.

Since the fat fusion coincided with the glass transition, the estimation of the $T_{g}$ of high milk-fat powder was impossible using the conventional calorimetric method (modulated dynamic scattering calorimetry: MDSC). To achieve a more valuable approximation, only the glass transition temperatures of low-fat milk powders were verified following the MDSC, as described by Syll et al., 2012. ${ }^{[32]}$ Approximately, $6 \mathrm{mg}$ of camel or cow milk powders were weighted in a hermetically sealed aluminum pan. In the first step, samples were rapidly cooled at a rate of $10^{\circ} \mathrm{C} \min ^{-1}$ to reach $-10^{\circ} \mathrm{C}$, using a differential scanning calorimeter (Q-1000, TA Instruments, Saint Quentin en Yvelines, France), calibrated with indium (the melting point is about $156.6^{\circ} \mathrm{C}$ ). Samples were held at $-10^{\circ} \mathrm{C}$ during $5 \mathrm{~min}$ to reach the equilibrium. Then, a single heating scan was performed at a rate of $3{ }^{\circ} \mathrm{C} \mathrm{min}^{-1}$ from $-10^{\circ} \mathrm{C}$ to $+150^{\circ} \mathrm{C}$. The glass transition temperature $\left(T_{g}\right)$ was then deduced from the obtained MDSC curve.

\section{Bulk density}

The camel and cow milk powders were gently pulverized without tapping or disrupting into a pre-weighted stainless steel vessel with a known volume. The bulk density was then estimated using the following equation:
Bulk density $\left(\mathrm{kg} \mathrm{m}^{-3}\right)=\frac{\text { powder weight }(\mathrm{kg})}{\text { vessel volume }\left(\mathrm{m}^{3}\right)}$

\section{Free fat determination}

The quantification of the free fat of camel and cow milk powders was performed as described by Schuck et al., $2012 .^{[33]}$ In fact, $50 \mathrm{~mL}$ of petroleum ether were poured into a glass vessel containing $10 \mathrm{~g}$ of camel or cow milk powders. The mixture was then vigorously shaken; and filtered to separate the liposoluble compounds from other components. The obtained filtrate underwent a quick evaporation at $60^{\circ} \mathrm{C}$ under vacuum, using a rotary evaporator (Heidolph LaboRota 4000/HB Efficient, Heidolph Elektro GmbH \& Co., Schwabach, Germany) to remove the petroleum ether. The free fat quantity (expressed in $\mathrm{g} 100 \mathrm{~g}^{-1}$ of total powder fat) was calculated using the following formula:

Free fat $=\frac{\text { weight of fat after evaporation }(\mathrm{g})}{\text { total powder fat }(\%)} \times 1000$

\section{Results and discussion}

\section{Physicochemical characteristics of milk samples}

The physicochemical characteristics of camel and cow milks are summarized in Table 1. Camel milk presents 
(A)

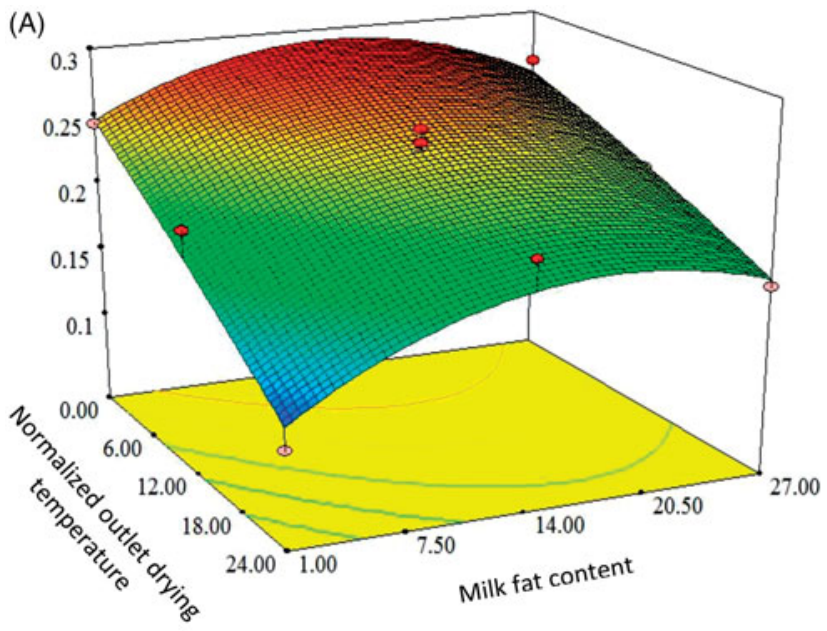

(B)

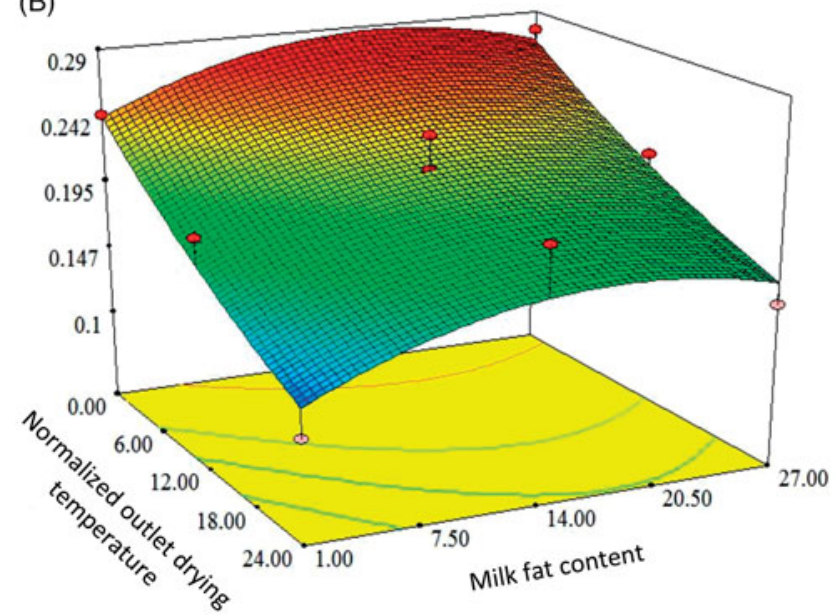

Figure 1. Three-dimensional response surfaces obtained for the water activity. A: camel milk powder; B: cow milk powder.

a slightly lower $\mathrm{pH}$ value (6.5) than that of cow milk $(\mathrm{pH}=6.7)$. The observed difference in $\mathrm{pH}$ values can be attributed to the high vitamin $\mathrm{C}$ (ascorbic acid) content of camel milk. The statistical analysis highlighted that, the milk fat content of cow milk was significantly higher than that observed in camel milk $(p<.05$, Table 1$)$. Besides, the protein and the lactose contents were insignificantly higher in camel milk as compared to cow milk ( $p>.05$, Table 1$)$. These differences could be associated with the species themselves, the geographic location, the feeding and veterinary practices. ${ }^{[1]}$

\section{Models validation}

The generated mathematical equations for water activity $\left(a_{w}\right)$, glass transition temperature $\left(T_{g}\right)$, bulk density, and free fat are presented in Table 4. The significance of models is evaluated by considering the $f$-test, the $p$ value and the lack of fit significance. The analysis of the characteristics of camel and cow milk
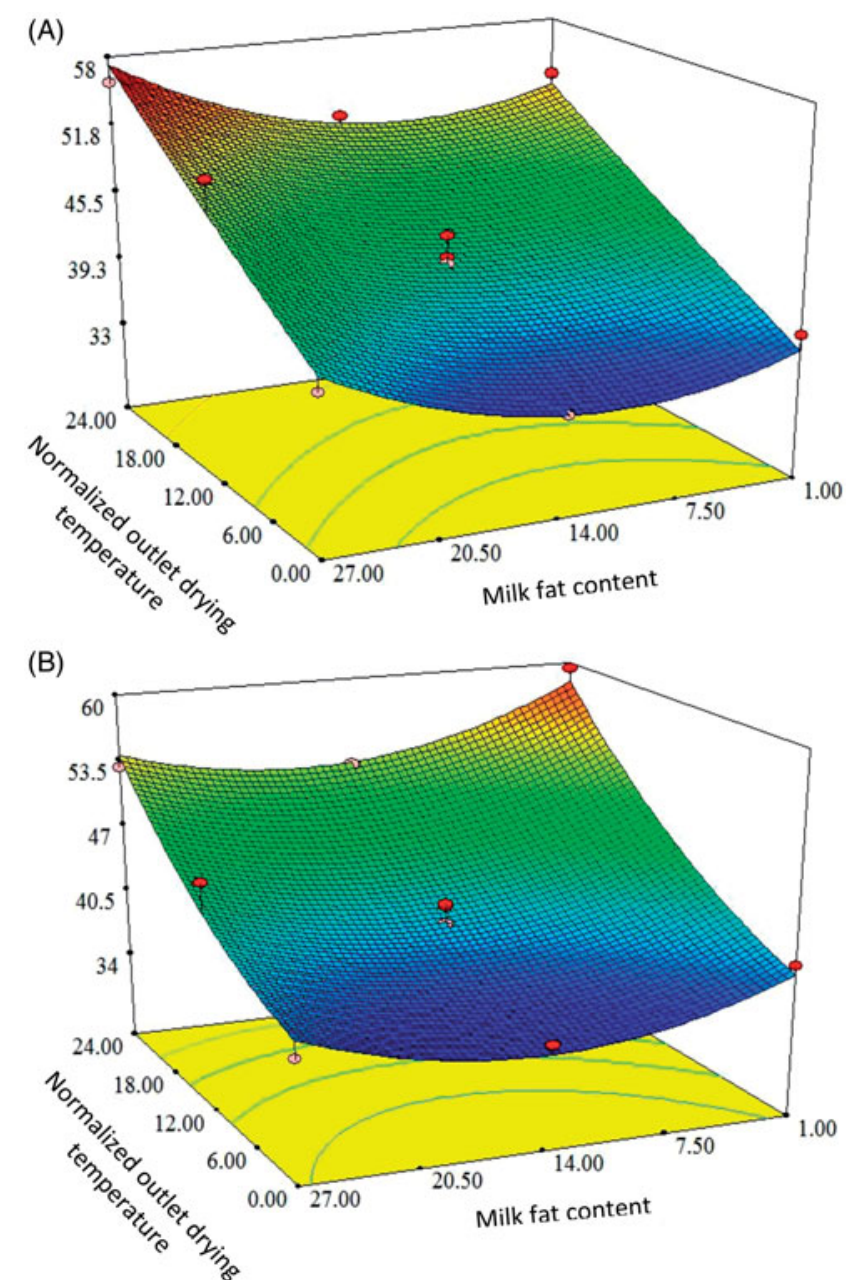

Figure 2. Three-dimensional response surfaces obtained for the glass transition temperature. A: camel milk powder; B: cow milk powder.

powders showed that, all quadratic models were significant $(p<.05$, Table 4$)$ with insignificant lack of fit (data not shown). For each milk powder characteristic, we have considered the coefficient of regression $R^{2}$, the adjusted $R^{2}$ and the coefficient of variation (CV) to evaluate the accuracy and the authenticity of the obtained mathematical models (Table 4). A low coefficient of variation $(\mathrm{CV}<10)$ is generally desired, as it allows the interpretation of the data variability and the model reproducibility. For the subsequent parts, each model equation and each factor effect will be discussed below.

\section{The thermodynamic behavior}

The $a_{w}$ and $T_{\mathrm{g}}$ represent the main routinely used thermodynamic parameters to evaluate the physicochemical stability of milk powders. The statistical analysis of the $a_{w}$ and the $T_{g}$ models showed an 
acceptable $R^{2}$ (close to $85 \%$, Table 4 ) and an adequate adjusted $R^{2}$ (Table 4 ), for cow and camel milk powders. All coefficients of variation were lower than 10 . Thus, the obtained models for water activity and glass transition temperature could efficiently be used, to describe the effects of the studied factors.

For both camel and cow milk powders, the air outlet drying temperature was the main influencing factor on $a_{w}$ and $T_{g}(p<.05$, Table 5). In fact, the threedimensional response surface plot showed a decrease of $a_{w}$ (Figure 1) and an increase of $T_{\mathrm{g}}$ (Figure 2), in relation to the increases of the drying temperature. Interestingly, the statistical analysis indicated a direct positive effect of the milk fat content on only the $T_{g}$ of camel milk powder $(p<.05$, Table 5, Figure $2(\mathrm{~A}))$. Furthermore, the glass transition temperature of both milk powders was positively affected by the quadratic term of milk fat content $(p<.05$, Table 5$)$.

As indicated in Table 3, a low water activity is associated with a high glass transition temperature. In fact, as a result of the increasing drying temperature, higher drying kinetics could be observed, causing a higher water removal. ${ }^{[24]}$ Fundamentally, water acts as a plasticizer; as it switches the glassy structure of milk powders to the rubbery or to the crystalline state. ${ }^{[16]}$ As a consequence, at low water activity, the glass transition temperature could be raised. ${ }^{[25]}$ On the other hand, it was reported that camel milk showed a high size of casein micelles (about $300 \mathrm{~nm}$ and $150 \mathrm{~nm}$ for camel and cow milks, respectively). ${ }^{[5]}$ We postulated that, the higher hydrodynamic diameter of camel milk casein micelles was involved in lowering the $T_{g}$ values of camel milk powder. In fact, the size of casein micelles may enhance not only the amount of nonsolvent water at the micellar surface, but also the lactose adsorption and exposure to the powder surface. The higher non-solvent water amount can reduce the viscosity of the particle surface and promote the lactose mobility in camel milk powder.

Jouppila \& Roos $1994,{ }^{[20]}$ reported that, the $T_{\mathrm{g}}$ is mainly related to the lactose content of milk powder and its behavior during dehydration and storage. These authors also observed a delayed lactose crystallization in milk powders containing fats. In fact, the presence of sufficient amounts of fat on the milk powder surface could represent a barrier to water uptake during storage. Thus, it can be deduced that milk fat content may decrease the rate of lactose crystallization, leading to the increase of the glass transition temperature.

Our findings showed that there was no direct effect of milk fat content on glass transition temperatures of cow milk powder. In fact, the total cow milk fat
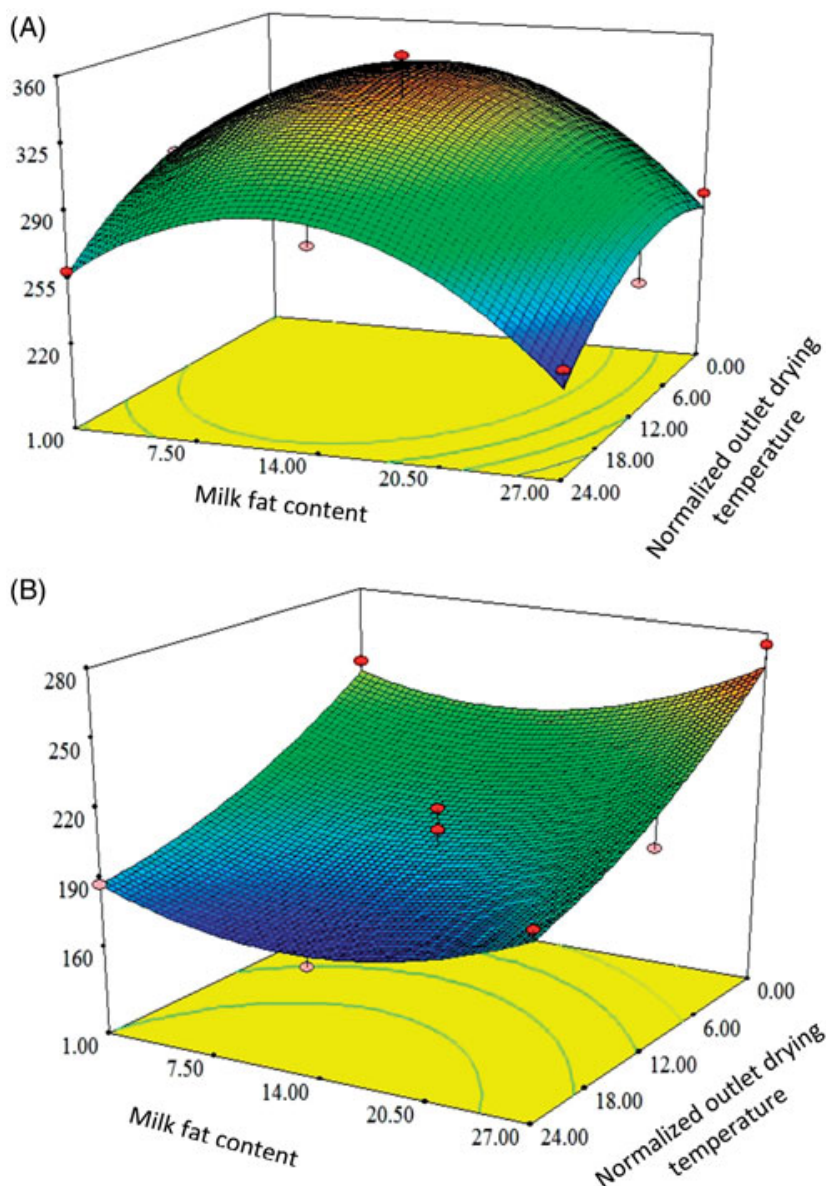

Figure 3. Three-dimensional response surfaces obtained for the bulk density. A: camel milk powder; B: cow milk powder.

would probably be exposed to the milk powder surface in the earlier steps of drying. Thus, the effect of milk fat content on the $T_{g}$ of cow milk powder was insignificant (Table 5). This is contrary to camel milk powder $T_{g}$, which was directly affected by the fat content level. We could explain this effect by the distribution of fat between the core and the surface of camel milk powder particles. Indeed, due to their natural small size ${ }^{[4]}$, some of the camel milk fat globules may still confined inside camel milk powder. Such fat distribution was observed in homogenized whole cow milk powder. ${ }^{[9]}$ In fact, it was reported that, the homogenization of cow milk fat had reduced their size; and had changed their distribution inside the milk powder particles. ${ }^{[31]}$ Moreover, it was reported that, fats continued their migration to the surface even at the earliest stage of storage. ${ }^{[34]}$ Overtime, this fact could promote the thickening of the fat layer at the external part of the camel milk powder particles. In this case, the effect of milk fat content could be meaningful. Hence, fat globules have indirectly increased the glass transition temperature of camel milk powder, by encapsulating the lactose. 


\section{Bulk density}

Milk powder density is directly related to the composition and the size distribution of its particles. Indeed, a high powder density is recommended to reduce packaging, transport, and storage costs. The generated mathematical models for bulk density showed a regression coefficient of 0.89 and 0.87 with a CV lower than 10 for cow and camel milk powders, respectively (Table 4). As shown in Table 5, the bulk density of cow and camel milk powders was dependent on the outlet drying temperature variation $(p<.05$, Table 5). In addition, milk fat content seemed to decrease only the bulk density of camel milk powder $(p<.05$, Table 5). Moreover, the quadratic term of milk fat content significantly affected both milk powders in a contrary manner $(p<.05$, Table 5$)$.

Figure 3 shows the three-dimensional surface response plot for the bulk density of cow and camel milk powders. In fact, with the increase of the outlet drying temperature, the milk powder particles are rapidly dried. As a consequence, their surface becomes less viscous, due to water evaporation, which could lead to the development of a hard crust. ${ }^{[35,36]}$ Indeed, this crust constitutes an elastic vapor-impermeable film, which enhances the formation of vapor bubbles inside milk powder. Exceeding a critical drying temperature, the particle surface could be broken because of the increase of internal tension forces. Thus, water evaporation could be enhanced, which would create a free volume inside the milk powder particles. This trend promotes the decrease of the bulk density of cow and camel milk powder.

Besides, our findings suggested that, there was no direct effect of milk fat content on the bulk density of cow milk powder. However, increasing the milk fat content has directly decreased the bulk density of camel milk powder $(p<.05$, Table 5$)$. It seemed like its particles underwent another development mechanism, during spray drying. In fact, compared to cow milk, Attia et al., 2000, ${ }^{[4]}$ had reported that camel milk fat globules are smaller with a stiffer phospholipidic layer (about 2 and $4 \mu \mathrm{m}$ for camel and cow milks, respectively). It can be suggested, that during spray drying, a minor part of fat globules (especially the largest ones) could be exposed to the free surfaces of whole or partially skimmed camel milk powders. This part of fat globules could form a discontinued hydrophobic layer. The major part of camel fat globules could be located in the core of particles, and they may preserve their initial structure. Such fat repartition could limit the water evaporation until the cracking of milk powder particles.
Studies of the behavior of homogenized cow milk fat globules during spray drying revealed that, a uniform distribution of small milk fat globules inside milk powder particles occurred. In fact, confocal laser micrographs of cow milk powder, underlined that small fat globules preserve their initial size inside powder particles. Furthermore, these small fat globules did not undergo coalescing, leading to the reduce of fat exposure on the surface of particles. ${ }^{[9,37]}$

Our results suggested that both studied factors (outlet drying temperature and milk fat content) acted in synergy without interaction $(p<.05$, Table 5$)$, to induce the formation of voluminous and porous particles for camel milk powder. Indeed, a second phenomenon, concerning the distribution of fat globules within camel milk powder particles, occurred simultaneously with the water removal. When the crust on the surface of camel milk powder particles is broken (i.e. high outlet drying temperature), the smallest fat globules leave the particle's core, over time. This fact allows the creation of an additional free volume inside powder particles. Thus, the bulk density of camel milk powder decreases with the increase of milk fat content.

\section{Free fat quantity}

Knowing and $\backslash$ or modeling the amount of free fat in dairy powders is of high importance. In fact, higher free fat was associated in most cases, with the deterioration of milk powder quality. The statistical analysis of free fat models showed an acceptable regression coefficient $R^{2}(0.89,0.91)$ and an adequate adjusted $R^{2}$ $(0.84,0.85)$, for cow and camel milk powders (Table 4), respectively. Contrary to cow milk powder, increasing the milk fat content leads to the decrease of the free fat quantity of camel milk powder $(p<.05$, Table 5). In addition, only in camel milk powder, a negative influence of drying temperature was detected $(p<.05$, Table 5). As such, this factor was also involved in a positive interaction with camel milk fat content $(p<.05$, Table 5$)$.

Few studies were conducted to understand the behavior of fat globules, during spray drying. ${ }^{[38]}$ It was reported that, the distribution of fat globules within the dried particles, depended especially on their size and composition. ${ }^{[7]}$ Since camel and cow milks showed different fat characteristics, ${ }^{[4]}$ it would be expected that fat evolution followed different mechanisms, during spray drying. Our results highlighted that, increasing the cow milk fat content resulted in an increase of free fat quantity of cow milk powder 


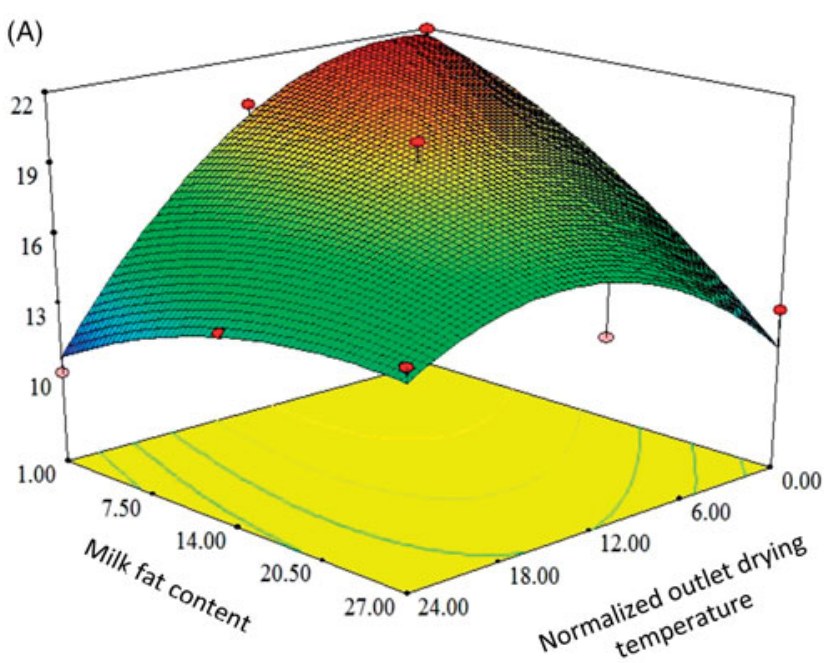

(B)

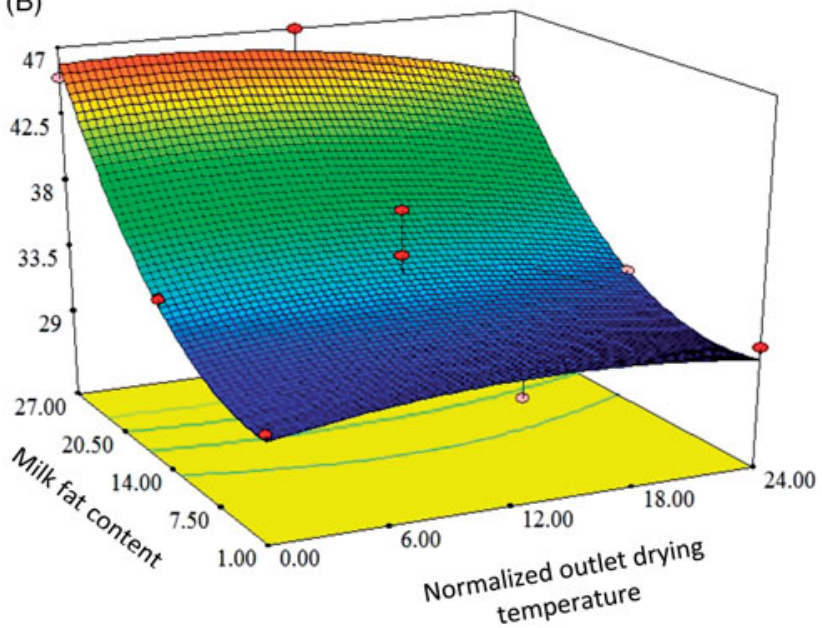

Figure 4. Three-dimensional response surfaces obtained for the free fat in term of total fat. A: camel milk powder; B: cow milk powder.

(Figure 4(B)). In fact, during spray drying cow milk fat may coalesce and may form fat patches. ${ }^{[9]}$ These patches are rapidly exposed to the surface. This fact could likely explain the positive effect of milk fat content on the free fat quantity of cow milk powder. However, our analysis pointed out a different behavior of camel milk fat, while producing camel milk powder. Indeed, increasing the camel milk fat resulted in a decrease of free fat quantity of the camel milk powder (Figure 4(A)). This fact suggested that, during spray drying camel milk fat will be imprisoned inside the dried particles instead of forming fat patches on the dried particles' surface (i.e. limited coalescence). In addition, the response surface methodology analysis showed that the milk fat content was involved in a positive interaction with the outlet drying temperature. Furthermore, our results suggested that, increasing the outlet drying temperature favored the confinement of fat globules in the internal part of camel milk powder particles (i.e. hinder their exposure to the surface). It can be deduced that, fat globules are firstly imprisoned in the core of camel milk powder particles. When approaching a critical outlet drying temperature, the dried particles would be cracked. Therefore, the imprisoned milk fat will be released and will reach the free surface of milk powder particles. Such condition endorses the exposure of free fat at the surface of camel milk powder and further validates the observed synergy of both factors (i.e. the outlet drying temperature and milk fat content) on the bulk density of camel milk powder.

\section{Conclusion}

In this work, a statistical investigation of some physicochemical properties of camel milk powder was performed. Fourteen experiments were created throughout the central composite face-centered experimental design. These experiments were conducted to find out the effect of the outlet drying temperature and the milk fat content, on the characteristics of camel and cow milk powders. Powder characteristics were analyzed following the surface response methodology. As expected, the variation of the outlet drying temperature was the main influencing factor on water activity and glass transition temperature of both milk powders. Therefore, we suggest that, camel and cow milks exhibit a similar thermodynamic behavior, during spray drying. However, the analysis of bulk density and free fat quantity highlighted some profound differences between camel and cow milk powders. These differences are related primarily to the characteristics of fat globules and their transfer to the surface of milk powder particles. In fact, for a more accurate understanding of the bulk density of camel milk powder, a balance between free and encapsulated fats should be considered. This balance could affect the water removal and the air bubbles formation, during drying. Thus, a different mechanism of the structuring of camel milk powder particles could be expected. It is worth mentioning, that this study is one of the preliminary works to understand the behavior of spraydried camel milk powder. This does not eliminate the fact that, further specific analysis should be conducted to validate our hypothesis.

\section{Disclosure statement}

No potential conflict of interest was reported by the authors. 


\section{Funding}

This project was financially supported by the higher education and scientific research ministry of Tunisia. The authors want to thank Mrs. Sawsan Derbel-Krichen for editing and improving the form of the manuscript.

\section{Note on contributors}

The authors want to thank Mrs. Sawsan Derbel-Krichen for editing and improving the form of the manuscript.

\section{References}

[1] Al-Haj, O.A.; Al-Kanhal, H.A. Compositional, Technological and Nutritional Aspects of Dromedary Camel Milk. Int. Dairy J. 2010, 20, 811-821. DOI: 10.1016/j.idairyj.2010.04.003.

[2] Konuspayeva, G.; Faye, B.; Loiseau, G. The Composition of Camel Milk: A Meta-Analysis of the Literature Data. J. Food Compos. Anal. 2009, 22, 95-101. DOI: 10.1016/j.jfca.2008.09.008.

[3] Felfoul, I.; Jardin, J.; Gaucheron, F.; Attia, H.; Ayadi, M.A. Proteomic Profiling of Camel and Cow Milk Proteins under Heat Treatment. Food Chem. 2017, 216, 161-169. DOI: 10.1016/j.foodchem.2016.08.007.

[4] Attia, H.; Kherouatou, N.; Fakhfakh, N.; Khorchani, T.; Trigui, N. Dromedary Milk Fat: Biochemical, Microscopic and Rheological Characteristics. J. Food Lipids 2000, 7, 95-112. DOI: 10.1111/j.17454522.2000.tb00164.x

[5] Farah, Z.; Rüegg, M. The Size Distribution of Casein Micelles in Camel Milk. Food Microstruct. 1989, 8, 211-216.

[6] Murrieta-Pazos, I.; Gaiani, C.; Galet, L.; Cuq, B.; Desobry, S.; Scher, J. Comparative Study of Particle Structure Evolution during Water Sorption: Skim and Whole Milk Powders. Colloids Surf. B. 2011, 87, 1-10. DOI: 10.1016/j.colsurfb.2011.05.001.

[7] Vignolles, M.L.; Lopez, C.; Le Floch-Fouéré, C.; Ehrhardt, J.J.; Méjean, S.; Jeantet, R.; Schuck, P. Fat Supramolecular Structure in Fat-Filled Dairy Powders: A Tool to Adjust Spray-Drying Temperatures. Dairy Sci. Technol. 2010, 90, 287-300. DOI: $10.1051 / \mathrm{dst} / 2009057$.

[8] Langrish, T.A.G.; Marquez, N.; Kota, K. An Investigation and Quantitative Assessment of Particle Shape in Milk Powders from a Laboratory-Scale Spray Dryer. Drying Technol 2006, 24, 1619-1630. DOI: $10.1080 / 07373930601031133$.

[9] Vignolles, M.L.; Lopez, C.; Madec, M.N.; Ehrhardt, J.J.; Méjean, S.; Schuck, P.; Jeantet, R. Fat Properties during Homogenization, Spray-Drying, and Storage Affect the Physical Properties of Dairy Powders. J. Dairy Sci. 2009, 92, 58-70. DOI: $10.3168 /$ jds.20081387.

[10] Nijdam, J.J.; Langrish, T.A.G. An Investigation of Milk Powders Produced by a Laboratory-Scale Spray
Dryer. Drying Technol. 2005, 23, 1043-1056. DOI: 10.1081/DRT-200060208.

[11] Nikolova, Y.; Petit, J.; Gianfrancesco, A.; Sanders, C.F.W.; Scher, J.; Gaiani, C. Impact of Spray-Drying Process Parameters on Dairy Powder Surface Composition and Properties. Drying Technol. 2015, 33, 1654-1661. DOI: 10.1080/07373937.2015. 1060494.

[12] Kim, E.H.-J.; Dong Chen, X.; Pearce, D. On the Mechanisms of Surface Formation and the Surface Compositions of Industrial Milk Powders. Drying Technol. 2003, 21, 265-278. DOI: 10.1081/DRT120017747.

[13] Schuck, P.; Méjean, S.; Dolivet, A.; Gaiani, C.; Banon, S.; Scher, J.; Jeantet, R. Water Transfer during Rehydration of Micellar Casein Powders. Lait. 2007, 87, 425-432. DOI: 10.1051/lait:2007016.

[14] Fyfe, K.; Kravchuk, O.; Nguyen, A.V.; Deeth, H.; Bhandari, B. Influence of Dryer Type on Surface Characteristics of Milk Powders. Drying Technol. 2011, 29, 758-769. DOI: 10.1080/07373937.2010. 538481.

[15] Gaiani, C.; Scher, J.; Ehrhardt, J.J.; Linder, M.; Schuck, P.; Desobry, S.; Banon, S. Relationships between Dairy Powder Surface Composition and Wetting Properties during Storage: Importance of Residual Lipids. J. Agric. Food Chem. 2007, 55, 6561-6567. DOI: 10.1021/jf070364b.

[16] Roos, Y. Importance of Glass Transition and Water Activity to Spray Drying and Stability of Dairy Powders. Lait. 2002, 82, 475-484. DOI: 10.1051/lait: 2002025.

[17] Hogan, S.A.; O’Callaghan, D.J. Influence of Milk Proteins on the Development of Lactose-Induced Stickiness in Dairy Powders. Int. Dairy J. 2010, 20, 212-221. DOI: 10.1016/j.idairyj.2009.11.002.

[18] Bhandari, B.R.; Howes, T. Implication of Glass Transition for the Drying and Stability of Dried Foods. J. Food Eng. 1999, 40, 71-79. DOI: 10.1016/ S0260-8774(99)00039-4.

[19] Roos, Y.; Karel, M. Plasticizing Effect of Water on Thermal Behavior and Crystallization of Amorphous Food Models. J. Food Sci. 1991, 56, 38-43. DOI: 10.1111/j.1365-2621.1991.tb07970.x.

[20] Jouppila, K.; Roos, Y.H. Glass Transitions and Crystallization in Milk Powders. J. Dairy Sci. 1994, 77 2907-2915. DOI: 10.3168/jds.S00220302(94)77231-3.

[21] Shrestha, A.K.; Howes, T.; Adhikari, B.P.; Bhandari, B.R. Spray Drying of Skim Milk Mixed with Milk Permeate: Effect on Drying Behavior, Physicochemical Properties, and Storage Stability of Powder. Drying Technol. 2008, 26, 239-247. DOI: 10.1080/07373930701831663.

[22] Kim, E.H.-J.; Chen, X.D.; Pearce, D. Surface Composition of Industrial Spray-Dried Milk Powders. 2. Effects of Spray Drying Conditions on the Surface Composition. J. Food Eng. 2009, 94, 169-181. DOI: 10.1016/j.jfoodeng.2008.10.020.

[23] Pisecky, J. Handbook of Milk Powder Manufacture; Niro AS: Denmark, 1997. 261 pp 24. 
[24] Schuck, P.; Dolivet, A.; Méjean, S.; Jeantet, R. Relative Humidity of Outlet Air: The Key Parameter to Optimize Moisture Content and Water Activity of Dairy Powders. Dairy Sci. Technol. 2008, 88, 45-52. DOI: 10.1051/dst:2007007.

[25] Schuck, P.; Blanchard, E.; Dolivet, A.; Méjean, S.; Onillon, E.; Jeantet, R. Water Activity and Glass Transition in Dairy Ingredients. Lait. 2005, 85, 295-304. DOI: 10.1051/lait:2005020.

[26] Hennigs, C.; Kockel, T.K.; Langrish, T.A.G. New Measurements of the Sticky Behavior of Skim Milk Powder. Drying Technol. 2001, 19, 471-484. DOI: 10.1081/DRT-100103929.

[27] Nikolova, Y.; Petit, J.; Sanders, C.; Gianfrancesco, A.; Desbenoit, N.; Frache, G.; Francius, G.; Scher, J.; Gaiani, C. Is It Possible to Modulate the Structure of Skim Milk Particle through Drying Process and Parameters? J. Food Eng. 2014, 142, 179-189. DOI: 10.1016/j.jfoodeng.2014.05.026.

[28] Sulieman, A.M.E.; Elamin, O.M.; Elkhalifa, E.A.; Laleye, L. Comparison of Physicochemical Properties of Spray-Dried Camel's Milk and Cow's Milk Powder. Int. J. Food Sci. Nutr. Eng. 2014, 4, 15-19. DOI: 10.5923/j.food.20140401.03.

[29] Abu-Lehia, I.H. Recombined Camel's Milk Powder. Colloques-CIRAD. 1998, 181-184.

[30] Horwitz, W.; Latimer, G. Official Methods of Analysis of AOAC International;Assoc. Off. Anal. Chem: Gaithersburg, MA, 2000.

[31] Hogan, S.A.; Famelart, M.H.; O'Callaghan, D.J.; Schuck, P. A Novel Technique for Determining Glass-Rubber Transition in Dairy Powders. J. Food
Eng. 2010, 99, 76-82. DOI: 10.1016/j.jfoodeng.2010. 01.040 .

[32] Syll, O.; Richard, B.; Willart, J.F.; Descamps, M.; Schuck, P.; Delaplace, G.; Jeantet, R. Rehydration Behaviour and Ageing of Dairy Powders Assessed by Calorimetric Measurements. Innov. Food Sci. Emerg. Technol. 2012, 14, 139-145. DOI: 10.1016/ j.ifset.2012.01.001.

[33] Schuck, P.; Jeantet, R.; Dolivet, A. Analytical Methods for Food and Dairy Powders; John Wiley \& Sons: Oxford, 2012.

[34] Gaiani, C.; Schuck, P.; Scher, J.; Ehrhardt, J.J.; ArabTehrany, E.; Jacquot, M.; Banon, S. Native Phosphocaseinate Powder during Storage: Lipids Released onto the Surface. J. Food Eng. 2009, 94, 130-134. DOI: 10.1016/j.jfoodeng.2009.01.038.

[35] Nijdam, J.J.; Langrish, T.A.G. The Effect of Surface Composition on the Functional Properties of Milk Powders. J. Food Eng. 2006, 77, 919-925. DOI: 10.1016/j.jfoodeng.2005.08.020.

[36] Cruz, M.A.A.; Passos, M.L.; Ferreira, W.R. Final Drying of Whole Milk Powder in Vibrated-Fluidized Beds. Drying Technol. 2005, 23, 2021-2037. DOI: 10.1080/07373930500210473.

[37] Ye, A.; Anema, S.G.; Singh, H. Behaviour of Homogenized Fat Globules during the Spray Drying of Whole Milk. Int. Dairy J. 2007, 17, 374-382. DOI: 10.1016/j.idairyj.2006.04.007.

[38] Schuck, P. Why a Bibliographic Review on Free Fat in Dairy Powders. Lait. 2007, 87, 183-185. DOI: 10.1051/lait:2007025. 